\title{
Skin Development in 14 to 60-Day-Old Guinea Pig Fetus
}

\author{
Desarrollo de la Piel del Feto de Conejillo de Indias de 14 a 60 Días
}

\author{
Diego Carvalho Viana ${ }^{1,2}$; Amilton Cesar dos Santos ${ }^{3}$; Fernanda Meneses Oliveira e Silva \\ Phelipe Oliveira Favaron ${ }^{3}$; Dayane Alcântara ${ }^{3}$; Antônio Chaves de Assis-Neto ${ }^{3}$ \& Maria Angélica Miglino ${ }^{3}$
}

\begin{abstract}
VIANA, D. C.; DOS SANTOS, A. C.; SILVA, F. M. O.; FAVARON, P. O.; ALCÂNTARA, D.; ASSIS-NETO, A. C. \& MIGLINO, M. A. Skin development in 14 to 60-day-old guinea pig fetus. Int. J. Morphol., 37(2):416-422, 2019.

SUMMARY: To contribute knowledge of an important experimental model for studies on skin embryology, a study was carried out to describe the morphological events of the skin during the intrauterine life of Cavia porcellus from the 10th to the 60th day of gestation. Embryos and fetuses were dissected, and the skin of the nasal, cranial, lumbar and anal regions was processed byoptical microscopy. At 30 days the first hairs, called lanugos, were observed in the cranial region. The morphological description showed that a few days can make a great difference in development.
\end{abstract}

KEY WORDS: Guinea pig; Skin differentiation; Embryology; Animal model; Histology.

\section{INTRODUCTION}

The Guinea pig (Cavia porcellus) is popularly known as the guinea pig. They are rodents belonging to the class Mammalia, Order Rodentia (Cooper \& Schiller, 1975) and they are reared for purposes such as research, food and companionship (Valim et al., 2004).

However, there is little research on skin embryology and annex development in rodents (Felipe, et al., 2006; Fortes, et al., 2013; Isola et al., 2013). Pig and primate skin is usually used as a research model (Reifenrath \& Spencer, 1985; Monteiro-Riviere \& Riviere, 1999).

For ethical reasons, investigation in primates is restricted and pigskin is preferred, because it can be obtained from animals slaughtered for consumption. However, the use of rodents has become popular because the skin has similar permeability to human skin (Príborsk \& Mühlbachová, 1990; Lundh et al., 1997), with or without hairs (Panchagnula et al., 1997).

Furthermore, the Guinea pig (Linnaeus, 1758) presents certain characteristics, such as adequate size, low maintenance cost and short gestation period and is considered an experimental animal (Björkman et al., 1981). Studies have shown similarities between the fetus circulation in the Guinea pig and humans (Kiserud \& Acharya, 2004), embryo membrane development, (Vasconcelos et al., 2013), reproductive cycle, (Stockard \& Papanicolaou, 1919), heart and liver anatomy at the end of gestation (Barbino et al., 2011), in addition to studies with toxicological texts tests (Savransky et al., 2013).

As a component of the wild fauna of South America that has been treated as a pet (Mueller, 2011), the Guinea pig, whose morphology to date has not been widely studied, deserves attention from morphologists because there are still large gaps regarding specific description of many of its anatomical aspects. The objective of the present research was to describe the morphological development of the skin in the nasal, cranial, lumbar and anal regions of the skin of the Guinea pig at different gestational ages.

\section{MATERIAL AND METHOD}

Animals: Thirty C. porcellus embryos and fetuses were used for this research, obtained from other previous research. The embryos and fetuses had gestational ages of 14, 18,

\footnotetext{
${ }^{1}$ Curso de Medicina Veterinária, Universidade Estadual do Região Tocantina do Maranhão - UEMASUL, Imperatriz (MA), Brasil.

${ }^{2}$ Universidade Estadual do Maranhão, Programa de Pós-Graduação de Mestrado em Ciência Animal, Laboratórios Multiusuários em Pesquisa da PósGraduação - LAMP/UEMA, Brasil.

${ }^{3}$ Departamento de cirurgia, Setor Anatomia dos Animais Domésticos e Silvestres, Faculdade de Medicina Veterinária e Zootecnia, Universidade de São Paulo (FMVZ/USP) - São Paulo (SP), Brasil.
} 
20, 30, 40, 50 and 60 days. The use of embryos was duly approved by the Committee of Bioethics, under protocol number 2521/2012.

Laboratories: the preparation and analysis by light microscopy (ML), scanning electonic microscopy (SEM) and transmission electron microscopy (MET) were carried out in the laboratories of the Department of Domestic and Wild Animal Anatomy at the Veterinary Medicine College at the University of São Paulo, Brazil/ Campus capital.

Dissection and light microscopy: the embryos and fetuses were weighed on scales and measured with a precision Mitotoyo ${ }^{\circledR}$ pachymeter (Table I). The photomicroscopic documentation was made with a Sony MAVICA 3.2 Mp digital camera. After measuring, the embryos and fetuses were dissected and the skin was processed. The material for light microscopy analysis was fixed in a $10 \%$ formaldehyde solution and then processed for blocking in Histosec-MERCK ${ }^{\circledR}$ paraffin (de Tolosa et al., 2003).The histological preparations were obtained in $5 \mathrm{~mm}$ thick semiseries cuts in a Leica RM 2155 Microtome, with a $100 \mu \mathrm{m}$ interval between those obtained in the dorsal region, with a total of five cuts per region, peridermis, epidermis intermediate and base layers, epidermal invagination and mesenchyme, that were cut in $\mathrm{H} / \mathrm{E}$ (Hematoxylin/Eosin), Picro-sirius and Gomori Trichrome. The microscopic photo documentation was made bya Leica DM 2000 photomicroscope. The embryos at the start of development were blocked whole.

Table I. Biometry related to gestational age, weight and size (Crown-rump) of of $C$. porcellus embryos and fetuses.

\begin{tabular}{cccc}
\hline $\begin{array}{c}\text { Gestational age } \\
\text { (days) }\end{array}$ & $\mathrm{N}$ & $\begin{array}{c}\text { Weight }(\mathrm{g}) \\
\text { min-max }\end{array}$ & $\begin{array}{c}\text { Crown-rump } \\
(\mathrm{cm})\end{array}$ \\
\hline 14 & 2 & $0,328-0,615$ & $0,8-1,2$ \\
18 & 2 & $0,612-0,641$ & $1,6-1,7$ \\
20 & 4 & $1,775-2,860$ & $1,4-1,9$ \\
22 & 2 & $3,758-3,800$ & $1,7-1,9$ \\
30 & 1 & 13,979 & $5,0^{*}$ \\
40 & 4 & $15,482-17,432$ & $5,0-5,3$ \\
45 & 2 & $16,585-16,775$ & 5,6 \\
50 & 2 & $39,789-39,694$ & $7,2-7,3$ \\
60 & 1 & 82,286 & $8,9^{*}$ \\
$>60$ & 3 & $79,499-85,975$ & $9,6-10,0$ \\
\hline
\end{tabular}

\section{RESULTS}

\section{Macroscopic Characteristics.}

14 and 18-day-old embryos: At 14 days only nondifferentiated cells were observed. At 18 days the cervical and cranial-caudal curvatures were accentuated, giving them a "C" shape, and the cephalic region was more developed than the caudal region. The skin was thin and transparent. Primitive structures were observed in the cephalic region, such as encephalitic vesicles (prosencephalitic, mesencephalitic and rombencephlistic), optical placoids without pigmentation and developing pharyngeal arches. The somites were delimited, and were seen dorsally in the caudal region. The tail was long and curved. The thoracic and pelvic limb buds were also observed (Fig. 1A,B).

20 day-old fetuses: The cervical and cranial caudal curves were less accentuated compared to the arching. The optical vesicles were asymmetrical and circular in shape, the auditory canal was slightly projected and the nasal region was delimited. The thoracic and pelvic limb buds were germinating (Fig. 1C).

22 day-old fetuses: The auditory canal was prominent and the encephalic region was more developed. The cervical curvature was less accentuated. The skin at this stage was thin and transparent, but more opaque. The optical vesicles changed their as symmetrical circular shape, observed at the previous age, for asymmetrical circle shape, the retina were already pigmented. At this stage of development the heart and liver areas of entry were ventrally observed, and the umbilical cord in the caudal region. The thoracic and pelvic limbs were at different phases of development. In the thoracic and pelvic limbs, depressions were observed between the digit rays indicating digit development. The tail was straight and short (Fig. 1D).

30 day-old fetuses: The optical vesicles were symmetrical and circular in shape, with differentiated pigmented retina and the nasal fossa were at the end of differentiation showing distinction of the nostrils and mouth, so that the facial characteristics could be defined. Discreet marking of the ears was observed. The first hairs, called lanugos, were observed in the cranial region. The thoracic and pelvic limbs in development presented distinct digits; four digits were observed on the thoracic limbs and three digits on the pelvic limbs. The digits were joined by an interdigital membrane (Figs. 2E).

35 day-old fetuses: Differentiation with nostril distinction because it suffered a keratinization process. Discreet opening of the ears was observed. The developing thoracic and pelvic limbs presented distinction of the digits and the interdigital membrane had begun to disappear. The genital tubercle and anal edge were developing (Fig. 2F).

40 day-old fetuses: Optical vesicles had pigmented retina and no eyelashes, prominent ears, formed nostrils, with 

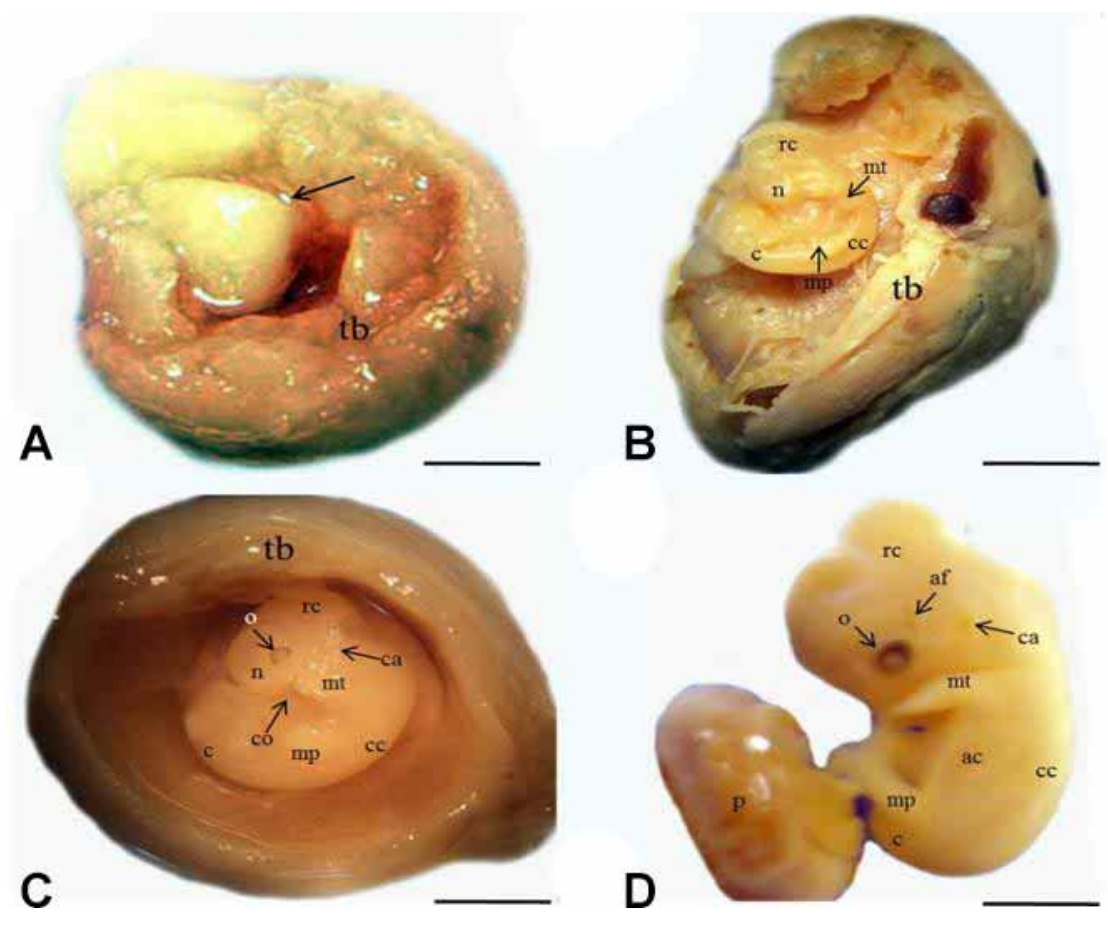

Fig. 1. Photograph of C. porcellus embryos at different development stages. Bar: $1 \mathrm{~mm}$.

Fig. 1. A: 14-day-old embryo (Arrow) inside the trophoblast (tf).

Fig. 1. B: cephalic region (rc), thoracic limb bud (mt), cervical curvature (cc), pelvic limb bud (mp), nasal region (n) and tail (c) of an 18-day-old embryo inside the trophoblast (tf).

Fig. 1. C: eye (o), cephalic region (rc), auditory canal (ca), thoracic limb bud (mt), cervical curvature (cc), pelvic limb bud (mp), nasal region (n), oral cavity (co) and tail (c) of an 18-day-old embryo inside the trophoblast (tf).

Fig. 1. D: eye (o), cephalic region (rc), pharyngeal arch (af), auditory canal (co), cervical curvature (cc), back arching (ac), pelvic limb (mp), tail (c) andf ormed placenta (p) in a 22-day-old embryo.
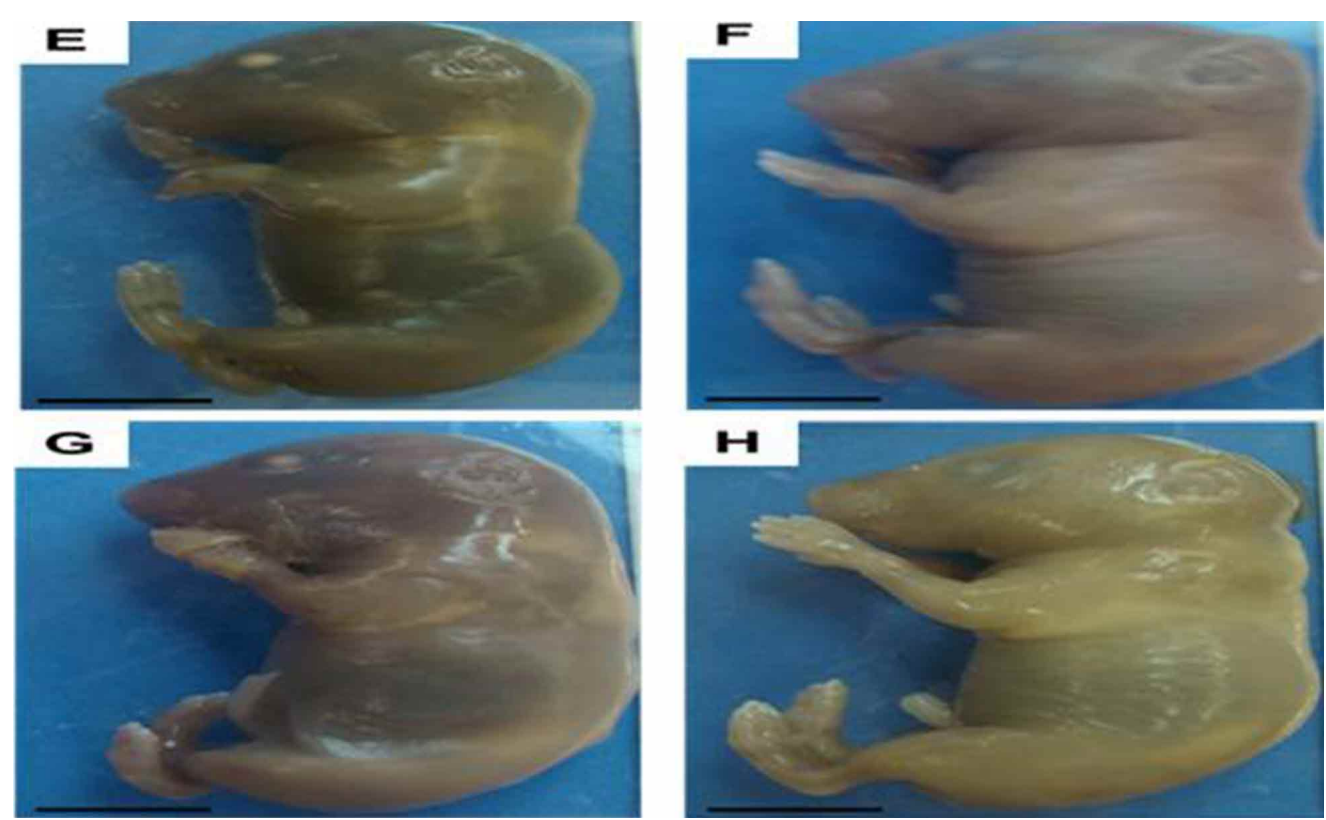

Fig. 2. Photograph of $C$. porcellus at $\mathrm{d}$ i f f e $\mathrm{r}$ e $\mathrm{n} \mathrm{t}$ development stages. E: 30 days. F: 35 days. G: 40 days. $\mathrm{H}:+40$ days. Bar: $2 \mathrm{~mm}$. the presence of small tactile hairs in the nasal region, open mouth with lip filter and lateral lip commissures. The skin was smooth and still transparent. Pore delimitation was observed with indices of hair follicles, but without developed hairs, except for the tactile hair sin the facial region. In the thoracic region dark marks were seen through the skin that indicated the presence of organs such as the heart and liver, and light marks that indicated the location of the ribs. The claws were not yet differentiated. The ge- nital tubercle and anal edge were seen in the perianal region (Figs. 2G,H).

45 day-old fetuses: The skin had thickened and was more opaque than at the previous age. In the cranial region dark marks were seen indicating the start of skin pigment differentiation. The claws were well-developed. In the perianal region, the genital tubercle and opening of the anal edge were seen (Figs. 3I). 

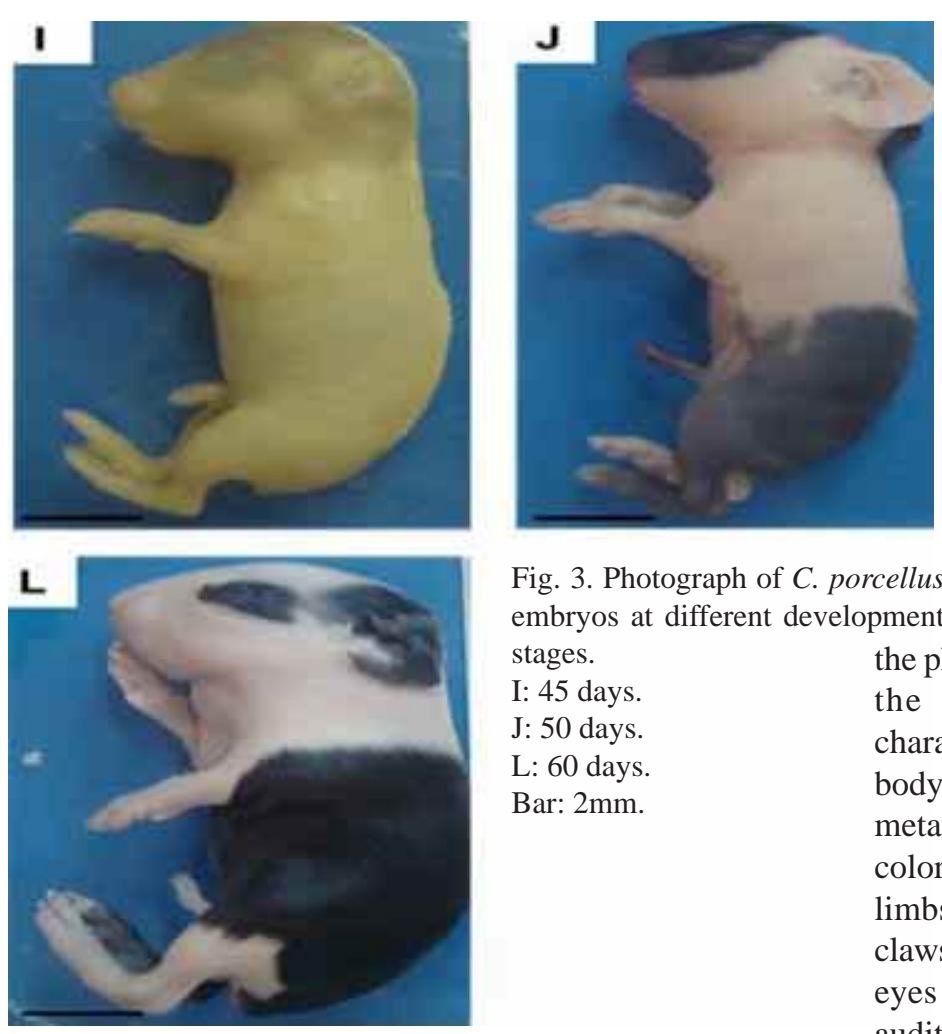

Fig. 3. Photograph of C. porcellus embryos at different development stages.

I: 45 days.

J: 50 days.

L: 60 days.

Bar: $2 \mathrm{~mm}$.
50 day-old fetuses: The fetuses showed complete differentiation of the body regions, with defined facial characteristics, such as closed eyes and small eyelashes, formed ears, nostrils presenting developed tactile hairs and with dark colored pigmentation. The skin had small, fine and non-pigmented hairs, widely distributed all over the body. The head had a larger quantity of hairs, as the tactile hairs of the facial region were the most developed. The skin of the distal region of the pelvic limbs, in the metatarsal plantar region, was thick, smooth and dark compared to the rest of the body. They showed differentiated genitalia, short tail without hair (Figs. 3J).

60 day-old fetuses: This stage was characterized as he phase of fetus maturity and at this time all the regions of the body were differentiated. Rough, long and characteristically colored hairs were distributed all over the body, except for the distal region of the pelvic limbs and the metatarsal plantar region; the latter had thick, smooth gray colored. The thoracic limbs had four digits and the pelvic limbs had three digits with well-developed light-colored claws. The facial characteristics were well defined, with open eyes with eyelashes, completely formed ears with open auditory canal and formed and open nostrils (Figs. 3L).
A
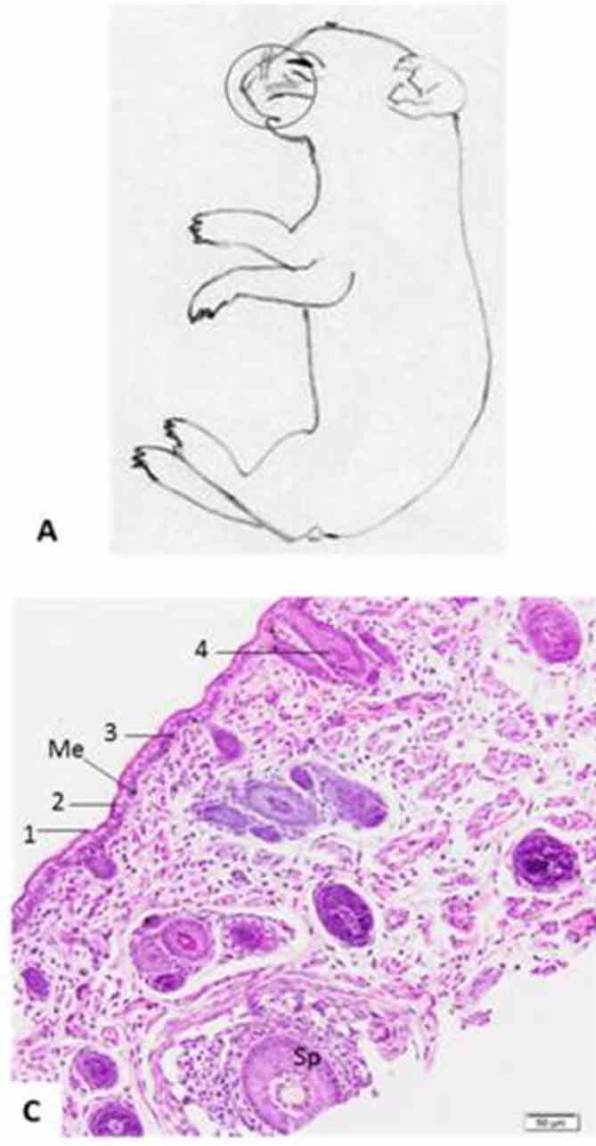

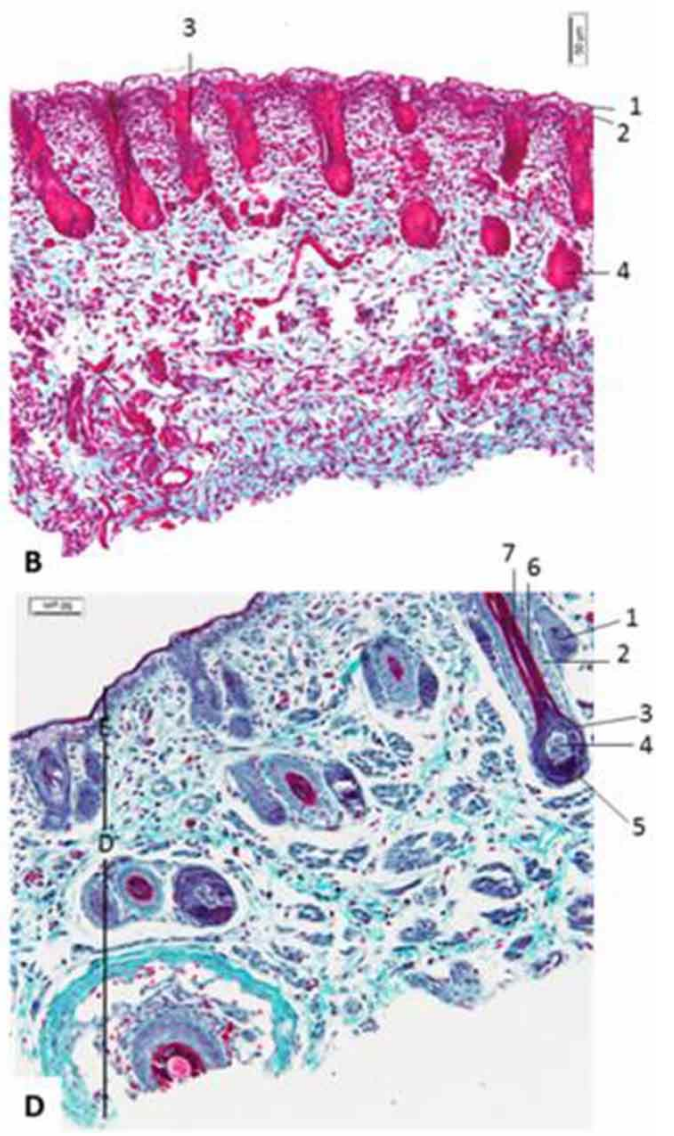

Fig. 4. Histological slices A: Drawing of the Guinea pig.

B: skin of the nasal region of a 30-day-old Guinea pig fetus. 1: Peridermis;

2: epidermal invagination;

3: Mesenchyme. HE, 20x.

C: skin of the dorsal region of a 40-day-old Guinea pig fetus.

1: Peridermis;

2: intermediate epidermis layer;

3: base epidermis layer;

4: Epidermal invagination;

5: Mesenchyme. Gomori trichrome, 20x.

D: skin of the dorsal region of a 50-day-old Guinea pig fetus.

1: Epidermis;

2: Epidermis base layer;

3: Hairy papila;

4: Nerve endings; DP: Papiladerme; Vs: blood vessels. Gomori trichrome. 
Microscopic characteristics: The Guinea pig skin did not show structural differences between males and females or between the skin of the regions of the nostril, brain, lumbar and anus. When seen under the light microscope, after routine hematoxylin and eosin (H.E.) staining, it was shown to be formed by the epithelial epidermis and the conjunctive dermis (Figs. 4-7).

The epidermis consists of a keratinized stratified pavement epithelium formed by three strata: the base, spinosum and corneum. The base or germerativum stratum

A
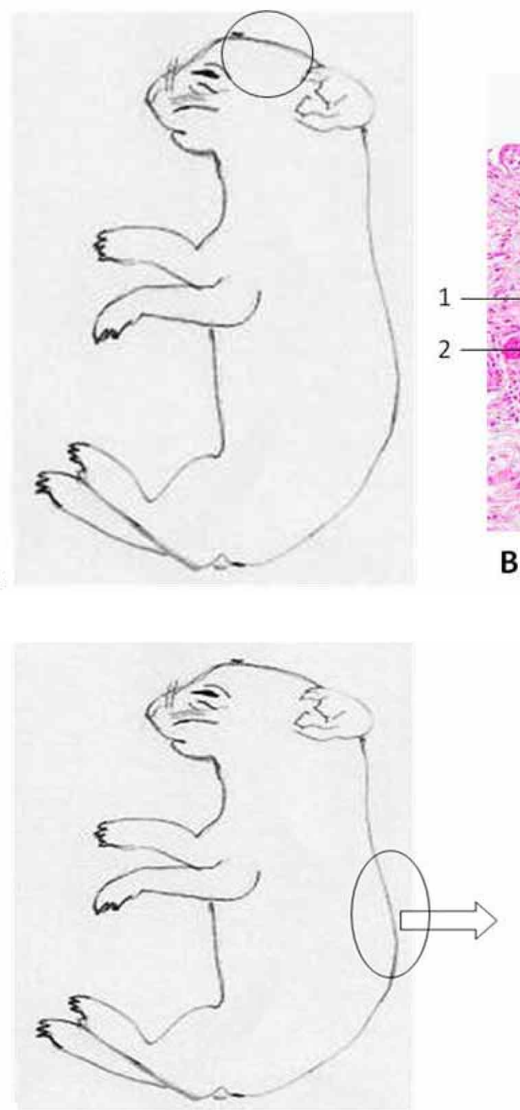

A
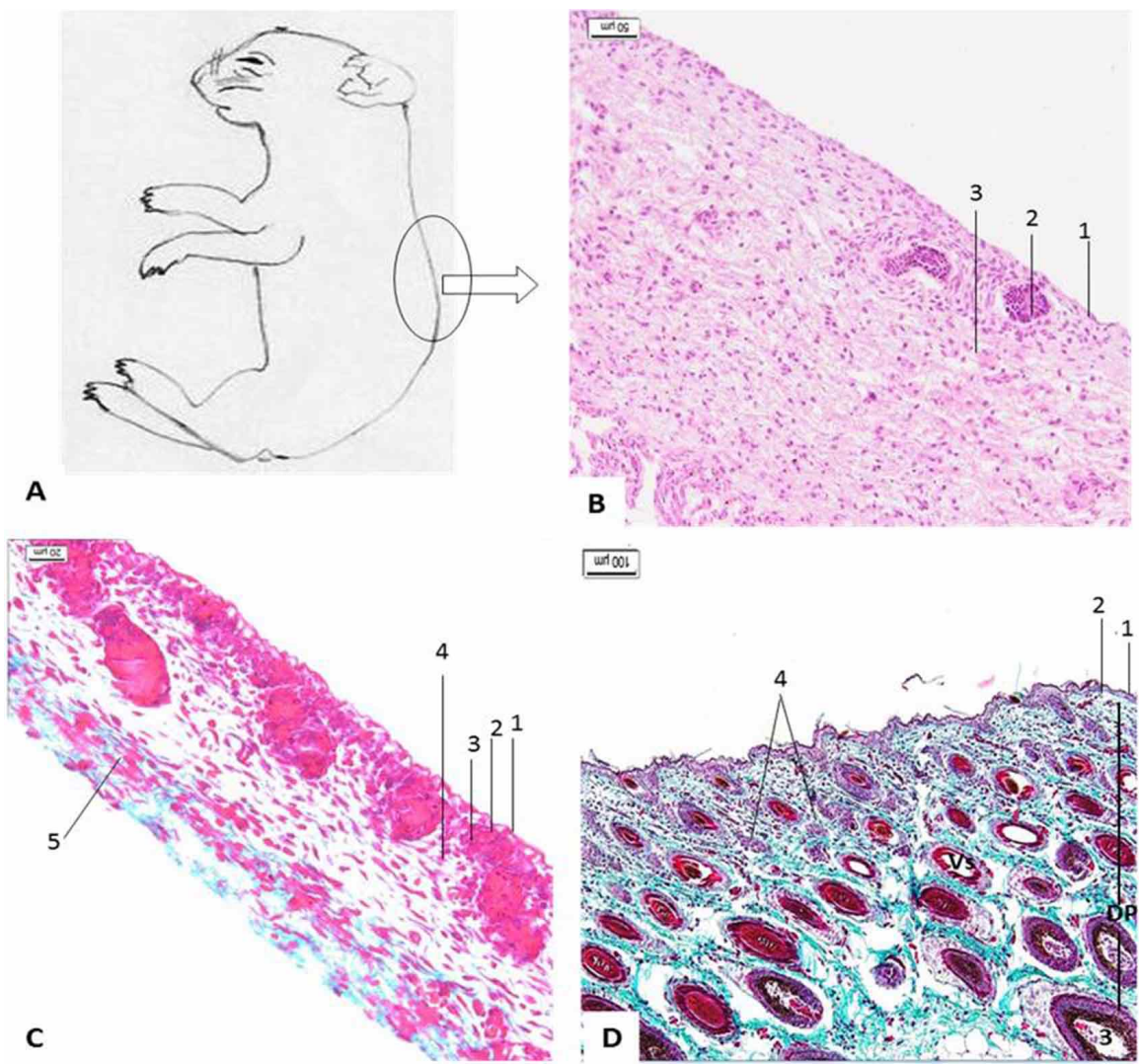

is a single layer of tall cylindrical cells, with central elongated nuclei perpendicular to the surface. The spinosum stratum is formed by two or three layers of polyhedral cells with central rounded nuclei, that flatten as they approach the surface. There is no granular stratum formed by polyhedral cells with granules of keratohyaline basophiles. The corneum stratumis characterized by flattened dead cells with no nucleus, full of keratin, forming a thin soft keratin surface layer. The epidermis is avascular and does not present intraepithelial glands and is nourished by the vascular network of the subjacent dermis.

Fig. 5. A. skin of the cranial region of a 30-day-old Guineapigfetus.

1: Epidermis;

2: Dermis;

3: Sudoriparous gland;

4: Hairy bud;

5: Hairy papila. HE.

Fig. 5. B. skin of the nasal region of a 40-day-old Guinea pig fetus.

1: Peridermis;

2: intermediate epidermis layer;

3: base epidermis layer;

4: Epidermis root edge;

5: Mesenchyme;

Sp: Hairy sinus; Me: Melanocytes. HE

Fig. 6. A. Drawing of the Guinea pig.

Fig. 6. B. skin of the lumbar region of a 30-day-old Guinea pig fetus.

1: Peridermis;

2: intermediate epidermis layer;

3: Epidermis root edge;

4: Hairy papilla.

Gomori trichrome.

Fig. 6. C. skin of the nasal region of a 40-day-old Guinea pig fetus.

1. Peridermis;

2: intermediate epidermis layer;

3: base epidermis layer;

4: Epidermis root edge;

5: Mesenchyme;

Sp: Hairy sinus; Me: Melanocytes. HE.

Fig. 6. D. skin of the nasal region of a 50-day-old Guinea pig fetus.

1: Sebaceous gland;

2: External edge;

3: Internal edge;

4: Dermic papilla;

5: Melanocytes;

6: Cortex;

7: Medulla;

E: Epidermis; D: Dermis. Gomori trichrome. 


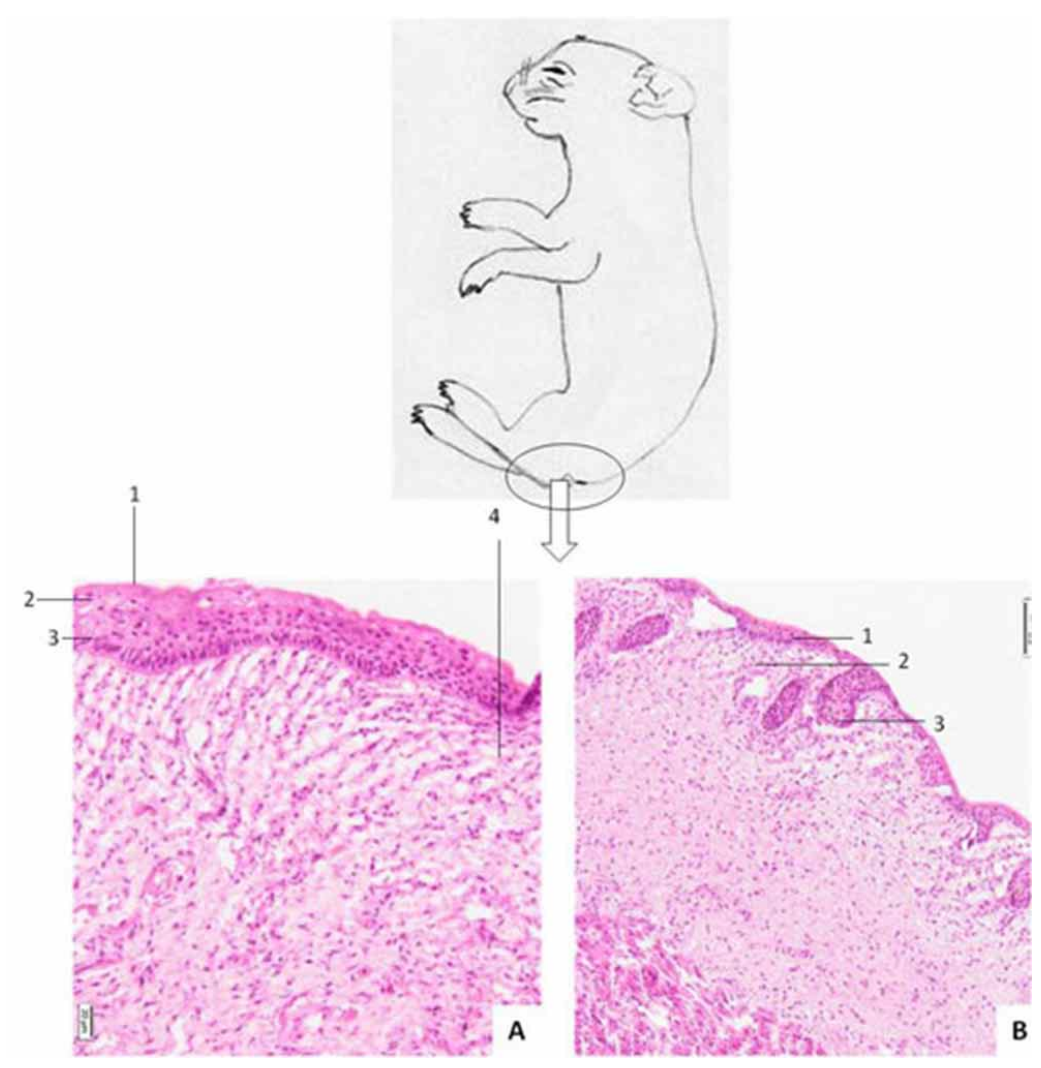

Fig. 7. Histological Slices.

A: skin of the anal region of a 30-day-old Guinea pig fetus. 1: Peridermis;

2: intermediate epidermis layer;

3: base epidermis layer;

4: Mesenchyme.

HE, 40x.

Fig. 7B: skin of the anal region of a 40-day-old Guinea pig fetus.

1: Epidermis;

2: Dermis;

3: Hair bud. HE, 20x.

\section{DISCUSSION}

The morphological and biometric aspects of the Guinea pig fetuses were characteristic of the different development periods studied, thus the embryo age could be calculated from these characteristics in this species. The skin was transparent throughout most of fetal period. At the start it was thinner, and began to become more opaque at 22 days and at 40 days it was smoother. Differentiation of skin pigmentation started at 50 days, when the skin was pigmented and showed small hairs, and it was thicker, smoother and dark in the distal region of the pelvic limbs. At 60 days it presented hairs with characteristic coloring distributed over all the body.

Knowledge of embryo and fetus morphological and microscopic characteristics is important as a base for studies in biotechnological reproduction, such as in vitro fertilization, embryo transference and helps determine congenital anomalies during the development phase (Fortes et al., 2013). The digits begin to develop at 22 days, but the union of these digits by a interdigital membrane was only seen in 30 day-old fetuses.

A study on agouti embryos showed many morphological similarities with human embryos. According to the living and Moore et al. (2012), the neuropores (cranial and caudal) were both closed in the agouti at 25 days, the thoracic limbs of the embryos at 35 days showed digit rays at the tips that were not observed on the pelvic limbs, as in human beings at 40 days, on the pelvic limbs the digit rays were observed presenting a shape similar to those of human embryos.

A study was also carried out with coypu (Myocastor coypus) fetuses that showed that 60 day-old fetuses are the same as the equivalent human fetus (Felipe et al). According to Sterba (1995), comparison made with coypu fetuses at stages equivalent to other mammal species makes it possible to predict the prenatal development phase of a species knowing the characteristics of others, regardless of the duration of the gestation period, although care should be taken regarding the particular differences in each species.

As with the agouti and coypu, the Guinea pig may also present characteristics to the human being during the embryonic phase. Thus, continuity of these studies could indicate which development phase is most suitable for carrying out a procedure that had been tested in these other species. 
C. porcellus skin was shown to be an extremely complex tissue, presenting various similarities to human skin and its internal characteristics, in addition to the development. The morphological description showed that a few days can make a big difference in development and applicability, than can direct pharmacological research related to the species.

ACKNOWLEDGEMENTS. We thank Coordenação de Aperfeiçoamento de Pessol de Nível Superior 8CAPES) and Fundação de Amparo à Pesquisa e Desenvolvimento Científico e Tecnológico do Maranhão (FAPEMA), Brasil.

VIANA, D. C.; DOS SANTOS, A. C.; SILVA, F. M. O.; FAVARON, P. O.; ALCÂNTARA, D.; ASSIS-NETO, A. C. \& MIGLINO, M. A. Desarrollo de la piel del feto de Conejillo de Indias de 14 a 60 días. Int. J. Morphol., 37(2):416-422, 2019.

RESUMEN: Con el objetivo de contribuir al conocimiento de un importante modelo experimental para estudios sobre embriología de la piel, se llevó a cabo un estudio para describir los eventos morfológicos de la piel durante la vida intrauterina de Cavia porcellus desde el día 10 hasta el día 60 de gestación. Los embriones y los fetos se disecaron y se procesó la piel de las regiones nasal, craneal, lumbar y anal, mediante microscopía óptica. A los 30 días se observaron los primeros vellos, llamados lanugos, en la región craneal. La descripción morfológica mostró que unos pocos días pueden marcar una gran diferencia en el desarrollo.

PALABRAS CLAVE: Conejillo de Indias; Diferenciación de la piel; Embriología; Modelo animal; Histología.

\section{REFERENCES}

Barbino, M. T.; Oliveira, C. M.; Fonseca, E. T.; Favaron, P. O.; Rodrigues, M. N. \& Miglino, M. A. Anatomia do fígado de fetos de Guinea pig em final de gestação (Cavia porcellus [Linnaeus, 1758]). Biotemas, 24(3):97-103, 2011.

Björkman, N.; Dantzer, V.; Hasselager, E.; Holm, H. \& Kjaersgaard, P. Perfusion in vivo of the porcine placenta. Fixation for EM. Placenta, 2(4):287-302, 1981.

Cooper, G. \& Schiller, A. L. Anatomy of the Guinea Pig. Cambridge, Harvard University Press, 1975. pp.259-63.

de Tolosa, E. M. C.; Rodrigues, C. J.; Behmer, O. A. \& de Freitas Neto, A. G. Manual de Técnicas para Histologia Normal e Patológica. $2^{\mathrm{a}}$ ed. São Paulo, Manole, 2003.

Felipe, A. E.; Masson, P. G.; Rodríguez, J. A. \& Alzola, R. H. External morphological characterization of 60-days gestation Myocastor coypus (Coypu) fetuses. Int. J. Morphol., 24(1):71-6, 2006.

Fortes, E. A.; Ferraz, M. S.; Bezerra, D. O.; Júnior, A. M.; Cabral, R. M.; Sousa, Fd.; Almeida, H. M.; Pessoa, G. T.; Menezes, D. J.; Guerra, S. P.; Sampaio, I. B.; Assis Neto, A. C. \& Carvalho, M. A. Prenatal development of the agouti (Dasyprocta prymnolopha Wagler, 1831): External features and growth curves. Anim. Reprod. Sci., 140(3-4):195205, 2013.

Isola, J. G. M. P.; Moraes, P. C.; Rahal S. C. \& Machado, M. R. F.
Morfologia, ultraestrutura e morfometria do tegumento da paca (Cuniculus paca Linnaeus, 1766) criada em cativeiro. Pesq. Vet. Bras., 33(5):674-82, 2013.

Kiserud, T. \& Acharya, G. The fetal circulation. Prenat. Diagn., 24(13):1049-59, 2004.

Lundh, T.; Boman, A. \& Akesson, B. Skin absorption of the industrial catalyst dimethylethylamine in vitro in guinea pig and human skin, and of gaseous dimethylethylamine in human volunteers. Int. Arch. Occup. Environ. Health, 70(5):309-13, 1997.

Monteiro-Riviere, N. \& Riviere, J. E. The Pig as a Model for Cutaneous Pharmacology and Toxicology Research. In: Tumbleson, M. E. \& Schook, L. B. (Eds.). Advances in Swine in Biomedical Research. 2nd ed. Boston, Springer, 1999.

Moore K. L.; Persaud, T. V. N. \& Torchia, M. G. The Developing Human. Clinically Oriented Embryology. $9^{\text {th }}$ ed. Philadelphia, Saunders/Elsevier, 2013.

Mueller, K. Skin diseases of rabbits and guinea pigs. Kleintierpraxis, 56(7):354-72, 2011

Panchagnula, R.; Stemmer, K. \& Ritschel, W. A. Animal models for transdermal drug delivery. Methods Find. Exp. Clin. Pharmacol., 19(5):335-41, 1997.

Príborsk, J. \& Mühlbachová, E. Evaluation of in-vitro percutaneous absorption across human skin and in animal models. J. Pharm. Pharmacol., 42(7):468-72, 1990.

Reifenrath, W. G. \& Spencer, T. S. Evaporation and Penetration from Skin. In: Bronaugh, R. \& Maibach, H. (Eds.). Percutaneous Absorption: Mechanisms, Methodology and Drug Delivery. New York, Marcel Dekker, 1985.

Savransky, V.; Sanford, D. C.; Syar, E.; Austin, J. L.; Tordoff, K. P.; Anderson, M. S.; Stark, G. V.; Barnewall, R. E.; Briscoe, C. M.; LemialeBiérinx, L.; Park, S.; Ionin, B \& Skiadopoulos, M. H. Pathology and pathophysiology of inhalational anthrax in a guinea pig model. Infect. Immun., 81(4):1152-63, 2013.

Sterba, O. Staging and ageing of mammalian embryos and fetuses. Acta Vet. Brno, 64:83-9, 1995.

Stockar, C. R. \& Papanicolau, G. N. The vaginal closure membrane, copulation, and the vaginal plug in the guinea-pig, with further considerations of the oestrous rhythm. Biol. Bull., 37(4):222-45, 1919.

Valim, M. P.; Amorim, M.; Serra-Freire, N. M. Parasitismo por Acari e Phthiraptera em cobaios [Cavia Porcellus (Linnaeus, 1758)] de ambientes rural e urbano nos municípios de Silva Jardim e Duque de Caxias, Rio de Janeiro, Brasil. Braz. J. Vet. Res. Anim. Sci., 41(4):2406, 2004.

Vasconcelos, B. G.; Favaron, P. O.; Miglino, M. A. \& Mess, A. M. Development and morphology of the inverted yolk sac in the guinea pig (Cavia porcellus). Theriogenology, 80(6):636-41, 2013.

Corresponding author:

Diego Carvalho Viana

Universidade Estadual do Maranhão (UEMA)

Laboratórios Multiusuários em Pesquisa da Pós-Graduação

- LAMP

Cidade Universitária Paulo VI, s/n

Tirirical - São Luis/MA

BRAZIL

E-mail: diego_carvalho_@hotmail.com

Received: 20-09-2018

Accepted: 02-01-2019 